\title{
Karel Vasak's Generations of Rights and the Contemporary Human Rights Discourse
}

\section{Spasimir Domaradzki ${ }^{1}$ (D) Margaryta Khvostova ${ }^{1}$ (D) $\cdot$ David Pupovac $^{1}$}

Published online: 6 September 2019

(C) The Author(s) 2019

\begin{abstract}
In the late 1970s, when Karel Vasak offered his concept of the three generations of rights, it was inclusive enough to embrace the whole spectrum of existing human rights. Forty years later, this paper explores the nature of contemporary human rights discourse and questions to what extent Vasak's categorization is still relevant. Our work discusses the evolution of the concept of human rights, the changing dichotomies of national and international, individual and collective, and positive and negative rights. This paper uses qualitative methods of content analysis and quantitative frequency analysis method to explore the nature of scholarly discourse presented in human rights journals. Our research findings highlight the dynamic evolution of contemporary human rights discourse. The paper specifically illustrates the increasing emphasis on collective and internationalist rights and the enhancement of human rights matters that are difficult to categorize using Vasak's approach. In doing so, the paper calls for the clarification of the language of contemporary human rights.
\end{abstract}

Keywords Karel Vasak · Generations of human rights · Individual rights · Collective rights · Group rights, human rights categorization

\section{Introduction}

It's been over four decades since Karel Vašák has introduced the three generations of rights. Although subject to severe criticism since the outset, his division of rights into generations has offered scholars, activists, and pundits a useful tool to

Margaryta Khvostova

m.khvostova@lazarski.edu.pl

1 Lazarski University, Swieradowska 43, 02-662 Warsaw, Poland 
organize the human rights discourse to the extent that it is difficult to run across a book or article that does not refer to Vašák's conceptualization directly or indirectly. Even critics of the concept itself, like Philip Alston, Jack Donnelly, or Hurst Hannum, recognize the practical existence of separate groups containing specific features. Similar to Vašák, Micheline Ishay also sees the history of human rights as the chronological development of the liberal and secular, socialist and eventually international institutionalization, and the right to self-development (Ishay 2008). Donnelly acknowledges the fact that each of the three groups overlapping with Vašák's generations is patronized by one of the three blocks during the Cold War: the West accenting the civil and political rights; the East pushing forward the economic, social, and cultural rights agenda; and the Third World accenting the importance of solidarity rights (Donnelly 1993, p. 235). Similarly, Hannum recognizes the importance of the 1970 s as a period of clear delineation of the particular groups of rights, their roles, mechanisms, and place in the political structures (Hannum 2019, p. 171).

Nevertheless, it has been over four decades since Vašák's generations entered the human rights debate. Being aware of the new global environment after the Cold War, the new challenges, tides of democratization and illiberal resurgence, new pressing problems like terrorism and migration that continue to profoundly influence the national and international priorities, and the evolving nature of the human rights discourse, we wonder whether Vašák's generations of rights are still valid.

Hence, through the application of qualitative and quantitative analyses of three renown human rights journals, we decided to identify the prevalent trends in the contemporary human rights discourse, and establish whether Vašák's categorization of rights still holds and if there is a need for a renewed discussion on the organization of the human rights discourse.

\section{Karel Vašák: Three Generations of Rights}

The classification provided by Karel Vašák, which offers the notion of three generations of rights (Vašák 1977, pp. 29-32), is probably the most practical, commonly used, and comprehensive categorization of human rights (Uvin 2002; Ishay 2008; Ife 2012; Wellman 2000; Bunch 1990; Downs 1993; Alston 1982; Tomuschat 2014; Stein 2007). Most importantly for our research, it encompasses the dichotomies used in major attempts of human rights classification: negative vs. positive rights, individual vs. collective rights, and national vs. international liability.

The first generation regards negative rights and corresponds to civil and political liberties. The second generation presumes a positive action of the state and includes social, economic, and cultural rights. ${ }^{1}$ The first two generations of rights have their corresponding covenants signed in 1966: the ICCPR for the first and ICESCR for the second (UN 1966a, 1966b). The sharp distinction between the two covenants lies in the

\footnotetext{
${ }^{1}$ The concept of negative rights ("freedoms from") and positive rights (rights to) was firstly addressed by Isaiah Berlin (1990).
} 
parties' obligations stemming from the respective Article 2.1. for each of them. The ICCPR relevant provision requires states" "respect and insurance" of the rights enlisted in the Covenant, whereas the ICESCR binds countries only of "taking steps" in certain direction aiming at the fulfillment of the Covenant's provisions. ${ }^{2}$ Finally, Vašák's third generation of human rights is referred to as "rights of solidarity." They require collective action of individuals as well as states and other political units (Vašák 1977, p. 29).

The first generation also has a long history of accenting liberty, dating back to the Magna Carta (1297) and including such milestone documents as the United States Bill of Rights (1791) and the Declaration of Rights of Man and of the Citizen (1789). Among those rights are the right to life, freedom of speech, freedom of religion, right to fair trial, equality before the law, and other civil and political rights. The second generation of equality rights was a product of the rapid nineteenth century industrialization and accompanying social and economic inequalities (Wellman 2000, p. 640; Alston 1982, p. 317). In the context of the emerging ideological confrontation after WWII, the communist camp staunchly supported the economic, social, and cultural rights. Their distinct feature is the prerequisite for active state involvement. Hence, the first two generations of rights were encompassed in the Universal Declaration of Human Rights (UN General Assembly 1948), with the West and the East clearly prioritizing respectively the first and second generations. While differentiating between the first and second generations of rights, Vašák contrasted the negative character of the former and the positive of the latter (Vašák 1977, p. 29). Moreover, both generations refer to individual rights and impose the corresponding duties onto the nation state.

The third generation of human rights is the most recent and vague in content. Collective rights that belong to this group were mentioned in the Stockholm Declaration (UN GeneralAssembly 1972), Rio Declaration (UN General Assembly 1992), and other international documents of declaratory character. ${ }^{3}$ Those rights include right to self-determination, economic and social development, healthy environment, natural resources, and participation in cultural heritage (Vašák 1977, p. 29). Hence, such rights are positive and collective and demand responsibility, which lies beyond the nationstate.

Thus, Vašák's differentiation between the three generations quite neatly fits into the three dichotomies based on the major approaches to human rights categorization: (1) negative (first generation) and positive (second and third generations), (2) individual (first and second generations) and collective (third generation), and (3) national (first and second generations) and international (third generation) liability as summarized in Table 1.

\footnotetext{
${ }^{2}$ Art. 2.1. of the ICCPR "Each State Party to the present Covenant undertakes to respect and to ensure to all individuals" and Art. 2.1. of the ICESCR "Each State Party to the present Covenant undertakes to take steps, individually and through international assistance and co-operation, especially economic and technical, to the maximum of its available resources, with a view to achieving progressively the full realization of the rights recognized in the present Covenant by all appropriate means, including particularly the adoption of legislative measures." A good example of the changing apprehension of the concept of human rights is that in 2008, additional protocol to the ICESCR was opened for parties willing to elevate the role of social, economic, and cultural rights to the one of the ICCPR (see Ssenyonjo 2011; Mapulanga-Hulston 2002)

${ }^{3}$ Such as follows: African Charter on Human and Peoples' Rights 1982; Declaration on the Right to Development 1986; United Nations Declaration on the Rights of Indigenous Peoples 2007.
} 
Table 1 Dichotomies of Vašák’s categorization

\begin{tabular}{|c|c|c|c|c|c|c|}
\hline & \multicolumn{2}{|c|}{$\begin{array}{l}\text { Negative/positive } \\
\text { dichotomy }\end{array}$} & \multicolumn{2}{|c|}{$\begin{array}{l}\text { Individual/collective } \\
\text { dichotomy }\end{array}$} & \multicolumn{2}{|c|}{$\begin{array}{l}\text { National/international } \\
\text { dichotomy }\end{array}$} \\
\hline & Negative & Positive & Individual & Collective & National & International \\
\hline 1st generation & $\mathrm{x}$ & & $\mathrm{x}$ & & $\mathrm{x}$ & \\
\hline 2nd generation & & $\mathrm{x}$ & $\mathrm{x}$ & & $\mathrm{x}$ & \\
\hline 3rd generation & & $\mathrm{x}$ & & $\mathrm{x}$ & & $\mathrm{x}$ \\
\hline
\end{tabular}

Ultimately, the third generation of rights assumes that they are positive, in terms of requiring active participation of duty-bearers; collective, in terms that focus on people or collectivities instead of individuals; and international, that they operate within the international relations erga omnes instead of the sole relationship between the state and the individual. In our research, we will stick to the thus understood categorization of Vašák's generations.

\section{Vašák's Critics}

An early critique of Vašák's generations was offered by Philip Alston already in the early 1980s. Approaching the question from international human rights perspective, he relied on the three stages in the process of formulating and implementing human rights 4 (Alston 1982, pp. 315-316). Concerned with the speed of the process for the promotion of the third-generation rights, Alston questioned whether the translation of the needs into specific legal norms at a relevant legislative forum was met and whether there is no practical blurring of the all three stages (Alston 1982, p. 316).

Vašák's generations were criticized also from semantic perspective, underlining the assumed generational exchange that could have undermined the already acknowledged human rights. Valid arguments were also raised that the extension of the human rights catalogue with new ones will move the accent from the old ones and thus weaken the whole system, since there is still a lot to be done in the field of human rights protection of these old rights.

Fredman also mentioned the need for rethinking the approach to the first- and second-generation rights as strictly negative and positive correspondingly. She argues that in the contemporary usage of the concept of human rights, demarcation between those positive and negative duties becomes increasingly blurred (Fredman 2006). Indeed, certain rights, like the right to a fair trial, fall to both categories since it simultaneously guarantees the individual right, but also requires the active state participation for its practical cherishment.

On the other hand, Kooijmans pointed out that a good right requires (a) a holder of the right, who can bring (b) an objectified claim against (c) a duty-bearer who must

\footnotetext{
${ }^{4}$ The three stages consisted of the following: (1) perception of a particular problem and the formulation of the relevant needs or aspirations; (2) the translation of some of these needs into specific legal norms through recognition by the relevant legislative forum; (3) the identification and elaboration of means by which to promote realization of the legal norm.
} 
honor the claim (Kooijmans 1990, p. 323). The collective claims against the vaguely defined participants in international relations can hardly meet this test. The critique adopts the dominant skepticism among western scholars that the third generation of rights confuses the fundamental principles for human rights protection with the demands of various groups and interests, and blends them with vaguely defined political rhetoric, thus bringing an overall negative impact to the international system of human rights protection.

However, this is not to say that international human rights should not be adjusted to the changing reality. Still, as critics stress, the existing catalogues offer substantial opportunities to further improve human rights protection within the existing framework (Alston 1982; Wellman 2000). Ultimately, as Alston and Kooijmans claimed, the introduction of the generations of rights was purposeful and aimed to advance such newly defined collective human rights as the ones promoted by Vašák (Alston 1982; Kooijmans 1990). However, regardless of the extensive critique, the third generation of rights enrooted itself into the human rights discourse.

Hence, for the sake of our research, it is important to stress that we do not take a position concerning the accuracy and implications of Vašák's generations. Our intention is much more modest, aiming to explore whether the generations, as offered by Vašák, are still able to accommodate the concept of rights and claims that circulate within international human rights discourse. We want to set up hypotheses, as to what are the dominant human rights themes, does the contemporary themes still fit to Vašák's categorizations, and eventually, do we need a redefinition of Vašák's pattern of categorization.

\section{The Possible Dissonance of Theory and Practice}

Before we turn to our empirical analysis, we need to acknowledge additional issues that give us the grounds to expect and that give us the reason to claim that the contemporary human rights discourse is different than forty years ago.

The first one concerns the paradigmatic change which occurred in the context of the right to development and subsequently took over the whole United Nations human rights doctrine. As Mariana Karadzhova noticed, together with the introduction of the right to development, the solidarity rights brought a new pattern of rights expansion through the adoption of political acts in the form of non-binding declarations. Starting from the UN GA resolution 41/128 in 1986, the idea of human rights indivisibility was aiming to equalize all human rights in value, regardless of their origin, history, or maturity (Karadzhova 2002, pp. 232-233). This process was reaffirmed in the Vienna Declaration and Programme of Action (Vienna Declaration and Programme of Action 1993). Thus, noticeable dissonance emerged between Vašák's notion of generations of rights and the official UN position. This formal, and yet only declaratory, decision practically reaffirmed the concerns about the negative impact of the attempts to equalize the three generations of rights. It is still not clear, whether the weakness came from the elevation of the third generation or the degradation of the first and second generations. All in all, third-generation rights promoters enthusiastically embrace this approach, since it offers further legitimization.

Secondly, it is difficult to prescribe minority rights into one of the Vašák's categories. On one hand, they clearly focus on protection of the interests of particular 
groups - racial, national, sexual, and other minorities. Thus, they cannot be considered first-generation rights since individualism plays a pivotal role for that category. However, freedom from discrimination falls under an umbrella of civil and political liberties. Yet still, freedom from discrimination and rights of minorities do not hold an equal denotation for the former refers to a negative liberty to be free from arbitrary will of others, be it the state or other groups of population, while the latter presumes that those actors bear a responsibility to provide certain rights and living conditions to minority groups.

In addition, scholars identify various dimensions of the changing human rights environment. The Cold War ended the period of bipolarity in international relations. Regardless of the endless scholar debates whether after the Cold War we live in Pax Americana, multipolar or multilayer system, there is a noticeable shift in the forces shaping the contemporary human rights discourse. In this respect, it is apparent that globalization with its spread of western liberal values and free market has dominated global politics.

This early post-Cold War enthusiasm grounded in the Washington Consensus and the third wave of democratization (Huntington 1992) was accompanied by severe intrastate conflicts that required prompt response, which was vested on the vaguely defined international community. Humanitarian Intervention and eventually Responsibility to Protect (R2P) challenged the concepts of sovereignty and state obligations towards own citizens, inflating the expectations towards human rights. This overly extensive interpretation extends the concept to various vaguely related fields, which Hannum defines aptly as humanitarianism (Hannum 2019, p. 134).

Regional integration processes also had an impact on the human rights discourse. After the Maastricht Treaty, the European Union pursued also axiological integration by drawing its own Charter of Fundamental Rights (Official Journal of the European Communities 2000) with a substantially new terminology, resembling the UN direction of squaring first and second generations of rights (Carleton n.d., Bisztyga 2011).

Micheline Ishay aptly embraces the complexity of issues that deserve attention in the globalization era, like the questions of labor and development rights, global environment and environment rights, migration and citizens' rights, or cultural rights (Ishay 2008, pp. 256-279).

Simultaneously, after a noticeable retreat of non-democratic states after 1989, since the early twenty-first century, a reverse tide of authoritarian renewal takes place. Accommodated in the global liberal market, China and Russia provided the recipe for non-democratic states how to regain position and power. Part of that process is what Freedman describes as human rights hybridity (Freedman 2014). Ultimately, terrorism, migration, poverty, and anti-western ideological resistance also leave their marks on the contemporary human rights discourse.

The aforementioned trends lead us to the identification of the "gray zones" of the contemporary human rights discourse that contain but are not limited to the following processes. Firstly, there is a noticeably growing role of international organizations and international legal bodies. Thus, state sovereignty was not only challenged, but states became subject to various axiological and terminological innovations triggering specific reactions. Secondly, the limited ability of the Council of Europe to produce comprehensive mechanisms for international protection of minorities within the Framework Convention for the Protection of National Minorities issued by the Council of 
Europe in 1995 revealed the legal and political limits to group rights protection, even within a group of likeminded and enthusiastic to extended human rights protection states. ${ }^{5}$ Thirdly, the human rights discourse embraces more and more dimensions and specific aspects. It does not only include questions related to ethics in business like pesticides (Dinham, Malik 2003), moral code of mining, fracking, but also bioethics (Albuquerque 2014; Pelluchon 2008; Raposo 2016) or robotics (Robertson 2014). Human rights have been also further profiled to secure the needs of particular groups like elderly or people with disabilities (Fredvang and Biggs 2012; Celik 2017; Council of Europe 2018). Fourthly, increasingly, the contemporary human rights debate attempts to reconsider the core human rights axiology through the lenses of postmodernist critical theory (Wang 2013) aiming to deconstruct human supremacism (Kymlicka 2018) and the extension of the basis of rights to sentientism (Baldissone 2010). Last but not least, the multicentricity, defined as the emergence of alternative to the state sources of legitimacy, like the European Union (Bisztyga 2011; Bojarski et al. 2014) or the Council of Europe (Letowska 2005) paved the way for changing the nature of the human rights discourse. Whereas initially the system was constructed through the uploading of national human rights practices to international level, nowadays, states are exposed to the reverse process of downloading from the extending human rights menu emerging in international organizations.

Notwithstanding all these new developments, we raise the question whether Vašák's generations are still suitable to grasp the complexity of the contemporary international relations? Where are the main accents of the contemporary human rights discourse? Ultimately, do we need a new paradigm to talk about human rights?

\section{Fitting the Contemporary Discourse into Vašák's Categories}

In order to provide an empirical analysis of the contemporary human rights narrative, we based the research on the articles published in three peer-reviewed academic human rights journals. The data was divided into the categories primarily based on Vašák's classification. The decision to use this categorization was due to the fact that Vašák's approach takes three major dichotomies into account: negative vs. positive rights, individual vs. collective rights, and national vs. international rights. Thus, we aim to establish (1) how comprehensive this attempt to analyze the human rights is in regard to the contemporary discourse, and (2) which topics of the contemporary discourse are neglected by this categorization.

Hereupon, we categorized the data in the following way. The first category-civil and political liberties - encompassed a wide range of topics that correspond to Vašák's group of the "first generation" rights. Namely, negative rights that refer to civil and

\footnotetext{
${ }^{5}$ In Article 3.2, it states that "Persons belonging to national minorities may exercise the rights and enjoy the freedoms (...) individually as well as in community with others." Therefore, even in legal terms, it is not clear how to treat minorities' rights. Moreover, it enlists not only first-generation rights, but also right to equal access to education and right to participation in cultural, social, and economic life. Thus, the Convention does not provide a clear designation of minorities. Moreover, in the General Considerations part, it acknowledges that "Framework Convention contains no definition of the notion of "national minority" since "it is impossible to arrive at a definition capable of mustering general support of all Council of Europe member States" (Council of Europe 1995).
} 
political freedoms. We based our understanding of the civil and political liberties on the International Covenant on Civil and Political Rights (UN1966a) with few exceptions. The major exception that we decided to make was with regard to the right to selfdetermination. This right stands out from this list because, unlike all the other rights, it clearly refers to a collective rather than an individual. Instead, the right to selfdetermination is usually associated with the decolonization process and may even be regarded as the oldest and foremost right of the third generation (Freedman 2014, p. 947). Thus, the first group includes the rights that are (1) negative and (2) individual, and (3) refer to civil and political liberties (Vašák 1977, 29), as well as (4) place the duty for their protection on the state.

The second group encompasses what Vašák calls the "second-generation" rights. Those rights are (1) positive and (2) individual; (3) refer to social, economic, and cultural rights (Vašák 1977, p. 29); and (3) consider state as a duty holder. Following the logic of the previous group, we used International Covenant on Economic, Social and Cultural Rights (UN 1966b) to determine the full list of rights belonging to this category.

As for the "third-generation" rights, Vašák defines them as "solidarity" rights and prescribes such issues as development, environment, peace, and common heritage to this generation (Vašák 1977, p. 29). However, there is no commonly accepted agreement on the exact list of those rights, and there is a tendency to prescribe all the rights that do not fit into the first two generations to this category. Therefore, it deserves further elaboration.

The initial list mentioned by Vašák in 1977 emerged as a reaction to decolonization process and ensured the rights for communities to develop independently (Freedman 2014, p. 948). Reacting to the flow of history, this generation was extended by some new notions, primarily humanitarianism and responsibility to protect doctrine (Teitel 2003, p. 91-92). Generally, those rights emerge amid international conflicts when the international community is expected to protect the rights of the communities affected by violence and ensure their right to peace. The baseline here is whether the collective is the holder of the right and whether it is subjected to the jurisdiction of the international community. However, as an exception, we assigned the topics that referred to issues such as genocide and mass atrocities to the first-generation rights due to the fact that they focus on the protection of essential individual right—right to life.

Moreover, emergence of new aspects of international cooperation that became associated with human rights, such as transitional justice and democratization, posed even more challenges to our categorization. In respect to those rights, we did not put them into the third-generation category since transition and democratization do not follow the logic of Vašák's list so obviously. Whereas the right to self-determination emerged in the Cold War process of decolonization, despite the extensive scholar attempts to apply colonial studies to the post-Cold War transitions, we refrain from bringing the right to self-determination and post-Cold War transitions and democratization under one denominator. Thus, in our analysis, the third-generation category embraced the rights referring to self-determination, development, peacebuilding, environment, humanitarianism, and responsibility to protect, while leaving the remaining topics, which are sometimes ascribed to this generation, to the uncategorized group, and thus, requiring further analysis. 
While gathering the data, we noticed some other tendencies that were not addressed by Vašák's categorization. Most notably, the overwhelming number of articles that were devoted to the minority rights cannot be regarded solely within the framework of the "first-generational" freedom from discrimination. As it was discussed in the first part of the article, rights of minorities in their contemporary understanding and implementation are positive in their character and thus require active participation of the state. To deal with this ambiguity, we decided to detach minority rights into a separate categorygroup rights. Though this violates the harmony of Vašák's division, the generalization of his theoretical proposition is too substantial to ignore. At the same time, some of the articles were devoted to the first-generational freedom from discrimination rather than to group rights. Thus, we performed additional context analysis of each bigram (word pair) mentioning minorities depending on whether they approached the problem from the group perspective.

Another ambiguous umbrella topic is migration. Here, our rationale in differentiating between the generations was individual/collective dichotomy. Thus, the topics of human trafficking, asylum seekers, and refugees were assigned to the first generation since they focused on infringement of personal freedoms, while the topic of migration per se was impossible to ascribe to any of the categories since it can be combined with rights from any of the categories.

Finally, the last group that presents a particular value for the research refers to the rights that we were not able to prescribe to any of the categories. Those rights present the "gray area" of the contemporary human rights theory and demonstrate the direction in which the concept evolves. They include such dimensions as truth and reconciliation commissions, migration, terrorism, reparations, sanctions, and forgiveness.

\section{Methodology}

In order to find out what is the framework of the contemporary human rights narrative, we sought to categorize articles published in the three human rights journals according to types of rights most frequently discussed in the abstracts. The abstracts generally provide a brief yet exhausting information about the topic, main thesis, and conclusion of the article. Unfortunately, not all the articles included abstracts. In those cases, we substituted the abstracts with the article introductions. Longer pieces of data were expected to return more frequent appearance of certain words and consequently, may result in misrepresentation of prevalent topics. In order to resolve this problem, we also used relative frequencies in determining how often the topics appear in the analyzed data.

The data is preprocessed following the common routines inherent to text analysis (Grimme and Brandon 2013). Therefore, the abstracts are analyzed by removing numbers, punctuations, symbols, and hyphens and subsequently, by assigning the frequency of each word utilized in the text to the respective abstract. Furthermore, stop words (the most common words in English) are removed from the analysis. ${ }^{6}$ Rather than solely basing our analysis on bag of words of approach, revolving only on single

\footnotetext{
"Some of the stop words include the following: "an," "and," "any," "are," "as," "the," "be," "because," "been," "nor," "of," and "on."
} 
word analysis (unigram analysis), we extended the study by providing some context. Consequently, in addition to unigrams, our analysis focused on the analysis of bigrams (word pairs). In this regard, stemming of words was not necessary. ${ }^{7}$

The analysis requires creation of a dictionary indicative of the aforementioned generation of rights. A specialized dictionary of this type does not exist, so it was necessary to create a dictionary which will assign relevant bigrams to particular generation of human rights. In order to do so, from the pool of all unigrams used in the abstracts (16,259 unique words), we selected unigrams inherent to the human rights discourse in general. On the basis of this selection, we have chosen all bigrams in which the relevant words appear. Finally, the relevant bigrams are categorized in one of the abovementioned categories. In total, the created dictionary consists of 2635 bigrams.

However, it is necessary to mention that some bigrams with certain semantic charge were excluded from the analysis. Firstly, excluded bigrams referred to either international institutions or specific countries. While we realize that international institutions play a crucial role in the contemporary human rights discourse, the nature of our analysis based on bigram categorization requires unambiguously denoted human rights, while the discussion of international organizations' functioning usually covers an umbrella of rights. As for the bigrams including countries, since bigrams consisted of two words, when one word denoted a name of a country, it was often impossible to precisely determine the category of rights based only on one word. Due to this, we had to omit such cases from our analysis, though this sphere undoubtedly deserves further research. Finally, articles written in response to a certain academic work were excluded from statistical analysis since they referred to already addressed topics.

While the approach to the generation of rights was a priori (as we predominantly base our theoretical framework on Vašák), the approach to the uncategorized rights is explorative. Due to the ambiguity in differentiation between some topics and their dependence on the context, the analysis will necessary suffer from a set of crude limitations and provide approximated results. Nonetheless, the statistical analysis offers a robust assessment of the contemporary human rights narrative.

Our research was divided into two main stages:

1) During the first-stage research, we gathered the data from the articles published in the academic human rights journals and determined the categories for classification of data using qualitative analysis. Thus, our analysis, grounded on Vašák's divisions and preliminary extended by us, included five categories: the three generations of rights, additional category of group rights, and uncategorized rights.

2) Then, aiming to provide reliable results and double-check the credibility of the results, we used quantitative method of statistical analysis.

In order to conduct the research, we focused on the three human rights academic journals. The reason for choosing the academic journals instead of other sources of information is that they provide reliable studies in the sequential manner and contain a sufficient number of peer-reviewed articles, which allows establishing general patterns and tendencies in the discourse. Moreover, the issues are published quarterly, which

\footnotetext{
${ }^{7}$ Stemming removes the ends of words to reduce the total number of unique words.
} 
allows to analyze the articles in a consecutive way. The number of journals was set on three since the number of the articles published in those journals since the early $2000 \mathrm{~s}$ (1545 articles) is sufficient to avoid accidental patterns and establish consistent trends. The journals included into the research are the following:

1) Human Rights Review

2) The Journal of Human Rights

3) Human Rights Quarterly

Considering that the majority of the editorial board members of those journals are the US scholars, it may be expected that the results will reflect the American human rights discourse. However, publication in those journals is available to authors from all over the world; they encompass a wide range of topics and do not favor any particular sphere of research, which provides a possibility to gather the statistics taking into account a comprehensive picture of the modern human rights discourse.

\section{Results of the Research}

The collected data comprises a variety of abstracts. The abstracts vary in the length (number of used characters); mean number of used characters is 1361, while the median is 1018 characters. ${ }^{8}$ Considering the number of words, mean number of words used in abstracts is 207.8 while the median number of words is $150 .^{9}$ In total, analysis is based on 164,387 words across 1375 abstracts (Fig. 1).

As it can be expected, the most frequently used terms are "human" and "rights." The term "rights" accounts for $2.9 \%$ while the term "human" accounts for $2.2 \%$ of all terms used in the abstracts. In accounting for distribution of the remaining terms, a selected set of additional words, assumed to be irrelevant, is excluded. ${ }^{10}$ Considering the absolute frequency of the terms, the most frequent terms include the following: "international," "political," "law," "state/s," and "social." Table 2 presents the ranking of the first 25 terms according their absolute and relative frequency.

A similar form of analysis is applied to bigrams (i.e., pairs of terms used together). The total number of bigrams across the abstracts is 135,537. As expected, the most frequently used bigram is "human rights" which accounts for approximately $2 \%$ of all bigrams. The set of most frequently used bigrams includes "international law," "United Nations," "transitional justice," "social (and) cultural," "economic (and) social," and

\footnotetext{
${ }^{8}$ The number of abstracts above 2500 characters comprises approximately $11 \%$ of all abstracts.

9 The share of abstracts above 500 words is approximately $7.5 \%$ while the number of abstracts of words below 100 words is approximately $13 \%$.

10 The list of terms includes the following: "human," "rights," "right," "this," "within," "many," "examines," "approach," "the," "also," "paper," “article," “can," "argue," "may," "recent," "form," "without," "part," "concludes," "analysis," "these," "must," "first," "examine," "however," "much," "one," "two," "three," "while," "number," "since," “argument," "claims," "whether," "necessary," “study," "upon,” "including," "yet," "attention," “rather," “among," "use," “often," “well," “end," “argues," "issue," "way," “but," "particularly," “increasingly," "less," “set," “address," "various," “although," “thus," "page,” “make," “fact,"

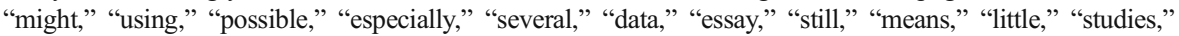
"four," "high," "across," "analyses," "towards," "indeed."
} 

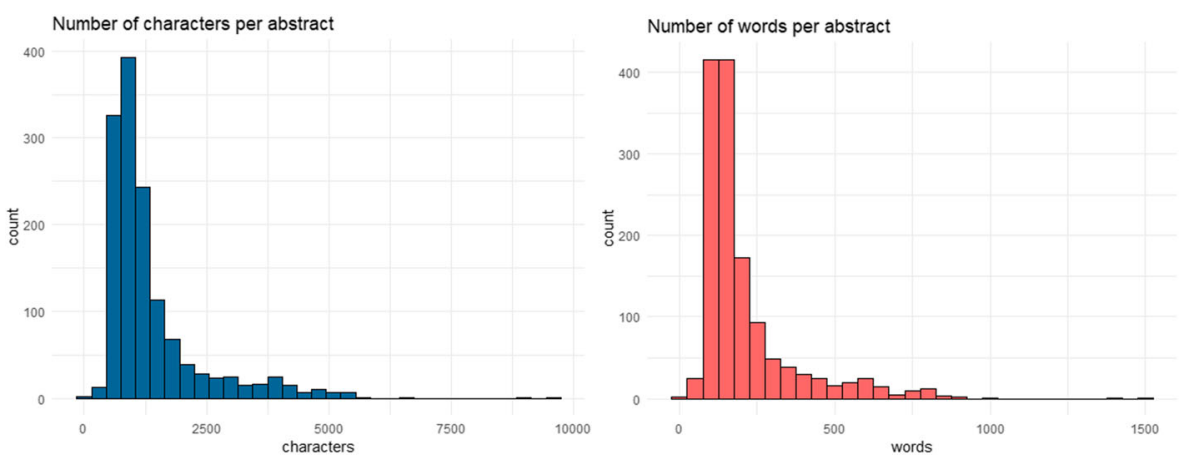

Fig. 1 Distributions of characters and words

"civil society." The following table presents 25 most frequently occurring bigrams (excluding "human rights") (see Table 3).

Table 2 Term (unigram) frequency rankings

\begin{tabular}{|c|c|c|}
\hline Rank & Ranking according to absolute frequency & Ranking according to relative frequency \\
\hline 1 & International & International \\
\hline 2 & Political & Political \\
\hline 3 & Law & Law \\
\hline 4 & State & State \\
\hline 5 & Social & Social \\
\hline 6 & War & Legal \\
\hline 7 & Legal & Justice \\
\hline 8 & Justice & War \\
\hline 9 & World & United \\
\hline 10 & National & Development \\
\hline 11 & Economic & Economic \\
\hline 12 & United & National \\
\hline 13 & Countries & World \\
\hline 14 & Development & Countries \\
\hline 15 & Policy & Policy \\
\hline 16 & Cultural & Case \\
\hline 17 & Violence & Cultural \\
\hline 18 & Government & Domestic \\
\hline 19 & Public & Violence \\
\hline 20 & Case & Global \\
\hline 21 & Civil & Violations \\
\hline 22 & Violations & Role \\
\hline 23 & Conflict & UN \\
\hline 24 & Global & Conflict \\
\hline 25 & People & Process \\
\hline
\end{tabular}


Table 3 Bigram frequency rankings

\begin{tabular}{|c|c|c|}
\hline Rank & Ranking according to absolute frequency & Ranking according to relative frequency \\
\hline 1 & International human & International human \\
\hline 2 & United Nations & United Nations \\
\hline 3 & International law & Transitional justice \\
\hline 4 & United States & Rights violations \\
\hline 5 & Rights violations & International law \\
\hline 6 & Transitional justice & United States \\
\hline 7 & Economic social & International criminal \\
\hline 8 & International criminal & Economic social \\
\hline 9 & Rights law & Rights law \\
\hline 10 & Civil society & Cultural rights \\
\hline 11 & Social cultural & Rights based \\
\hline 12 & Cultural rights & Civil society \\
\hline 13 & International community & Social cultural \\
\hline 14 & Universal declaration & Women's rights \\
\hline 15 & Women's rights & Court human \\
\hline 16 & Indigenous peoples & Universal declaration \\
\hline 17 & Rights based & Social rights \\
\hline 18 & Civil political & Rights abuses \\
\hline 19 & Declaration human & Truth commissions \\
\hline 20 & Political rights & Declaration human \\
\hline 21 & Court human & Rights discourse \\
\hline 22 & Truth commissions & International community \\
\hline 23 & Rights abuses & Rights norms \\
\hline 24 & Rights discourse & Self-determination \\
\hline 25 & Cold war & Rights abuses \\
\hline
\end{tabular}

The results of the frequency analysis of bigrams across categorization of rights are displayed in Table 4. The abstracts' bigram frequency analysis demonstrates that the most discussed category of human rights in the period of 2000 to 2017 is the first generation or rights, which accounts for 336 abstracts in total. The second generation is discussed twice as less than the first (165 articles), and the third is somewhat less than the second (125 articles). However, the analysis shows that the number of abstracts devoted to the group rights is higher even than second-generation rights (174 articles). Finally, the number of articles which cannot be assigned to any generation of rights is 206. At the same time, it is important to mention that prescription of the abstracts to only one category may sometimes omit some important aspects since oftentimes the article may refer to rights from different categories simultaneously. A number of articles devoted equal space to multiple generations of rights. Most frequently articles combine discussion of the first generation of rights with other generations of rights. In this respect, the first and the second generations of rights are equally discussed in 14 articles; the first and the third generations of rights are equally discussed in 11 articles; 
Table 4 Distribution of articles across categories of rights

\begin{tabular}{llllll}
\hline & $\begin{array}{l}\text { First } \\
\text { generation }\end{array}$ & $\begin{array}{l}\text { Second } \\
\text { generation }\end{array}$ & $\begin{array}{l}\text { Third } \\
\text { generation }\end{array}$ & Group rights & No category \\
\hline $\begin{array}{l}\text { Absolute frequency } \\
\begin{array}{c}\text { Absolute frequency: bootstrapped 95\% } \\
\text { confidence intervals (rounded) }\end{array}\end{array}$ & 336 & 165 & 125 & 174 & 206 \\
$\begin{array}{l}\text { Relative frequency } \\
\begin{array}{l}\text { Relative frequency: bootstrapped 95\% } \\
\text { confidence intervals (rounded) }\end{array}\end{array}$ & $322-382$ & $143-187$ & $105-145$ & $152-196$ & $82-230$ \\
\hline
\end{tabular}

Note: the total number of cases in relative frequency is larger in comparison with that in absolute frequency because all articles can be uniquely assigned to particular group of rights

the first generation of rights and group rights are discussed in 26 articles; and the first generation of rights and rights which cannot be categorized were discussed in 36 articles. Finally, our dictionary was not relevant for categorization of 216 articles.

In order to provide a more nuanced analysis, we also used the relative frequency of bigrams. ${ }^{11}$ The relative bigram frequencies slightly differ from the absolute frequencies. Here, the first generation as well scores the highest (352 articles); however, it is followed not by the group rights (151 articles), but by the second generation of rights (221 articles). Finally, the third generation of right and the articles which cannot be categorized into any of the generations of rights are 183 and 253 articles, respectively.

The dominant bigrams in the first generation or rights are "civil society," "war crimes," "human dignity," "death penalty," "crimes (against) humanity," "property rights," "freedom of association," and "religious freedom." The most frequent bigrams in the second generation of rights are "economic social," "cultural rights," "labor rights," "right (to) health," "rights (to) education," and "socioeconomic rights." The most numerous bigrams in the third generation of rights are "self(-)determination," "international (and) humanitarian," "developing countries," "peace process," "development (of) human," and "economic development." On the other hand, in the category of group rights, some of the most frequently used bigrams are "women's rights," "indigenous peoples," "children's rights," "minority rights," "LGBT rights," and "racial discrimination." Finally, some of the bigrams which are characteristic for the group of bigrams which were not classified in any of the previous classes of rights are "transitional justice," "truth commissions," "human trafficking," "displaced persons," "anti(-)trafficking," and "migrant smuggling" (we will discuss this category in detail below).

Next, we have examined the distribution of generation of right across time. Figure 2 demonstrates that across years 2000-2017, by and large, the distribution of bigrams across generations of rights is fairly stable. Naturally, there is some variation in a number of bigrams across the time. However, overall, the pattern seems to be invariable

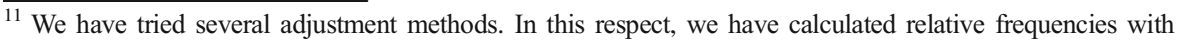
respect to total number of bigrams used in abstracts and relative frequency with respect to categorized number of bigrams. These adjustments do not make any difference with respect to the final results. The results presented here reflect the adjustment for the frequency of bigrams as categorized in generation of rights in the dictionary.
} 


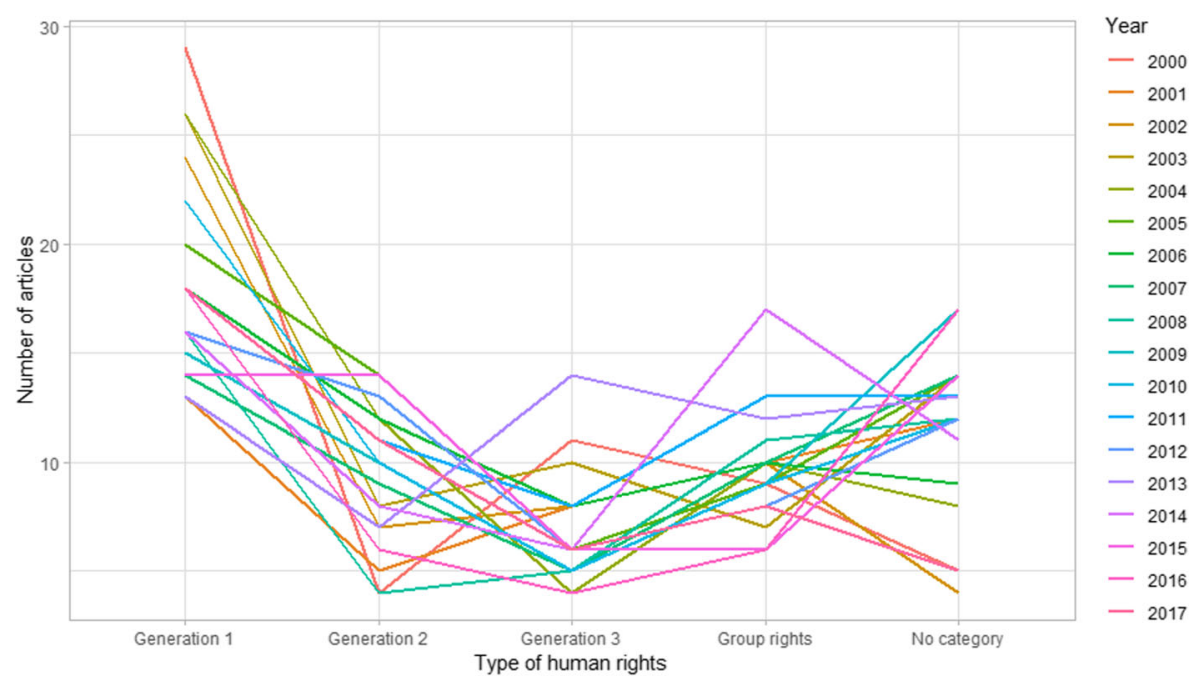

Fig. 2 Categories of rights across years

in that dominant category is the first generation of rights, followed by the category of groups of rights. The least frequently addressed topics in the articles are the second generation of rights and the third generation of rights (see Fig. 2).

Nevertheless, a closer look at the distribution of abstracts across times provides some indication that in the last two decades, generation 1 rights are gradually playing a less important role in human rights debates (see Fig. 3). However, the variation across years is quite substantial providing no certainty with respect to the hypothesized declining trend.

The most important area of the present research, however, refers to the bigrams which could not be categorized in any of the aforementioned four categories of rights. On the basis of the qualitative explorative analysis, we have determined that

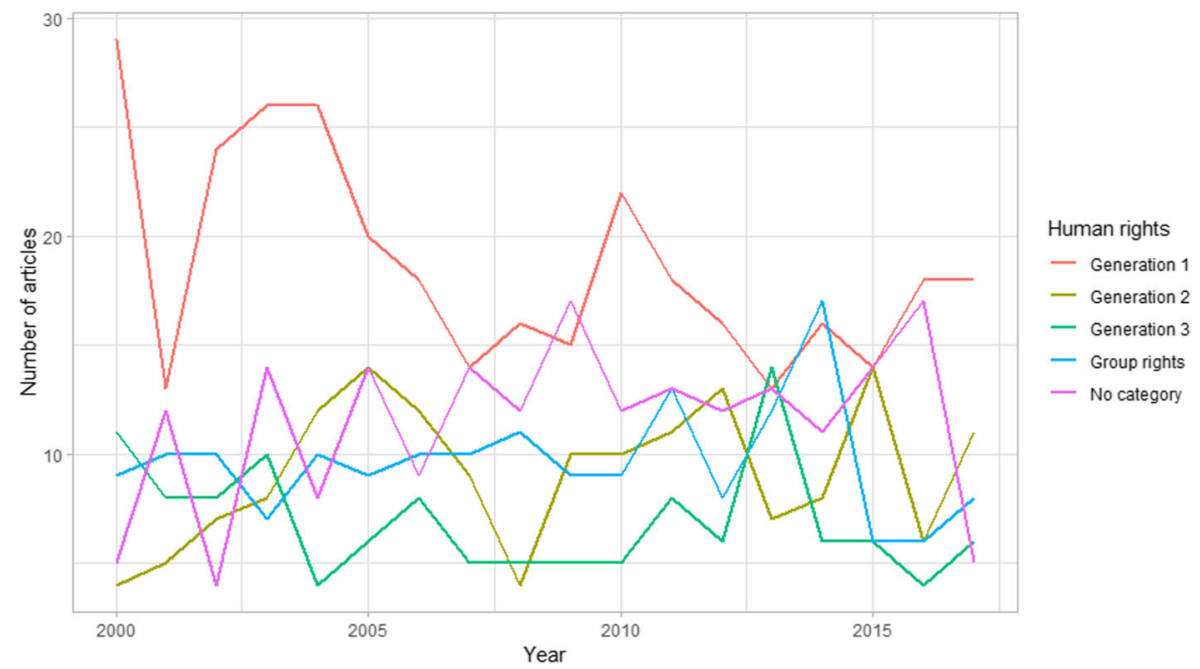

Fig. 3 Generation of rights across years 
uncategorized bigrams exhaustively refer to the rights connected to the following: transition, security and terrorism, migration, sanctions, warfare, eugenics and science, and identity. Furthermore, since the transition category was quite broad and embraced multiple aspects of this process, we created additional subcategories referring to the following: transition and democratization, history and memory, and transitional justice (including reconciliation, forgiveness, and retributions).

Then, the category of migration embraced the different aspects of immigration and migrants' rights. Though one might argue that those rights should be considered a part of the first generation, we concluded that those topics do not directly address firstgeneration rights, unlike, for example, the rights of asylum seekers.

Next, the identity category stands quite close to group rights as well as cultural rights of the second generation. Yet still, we decided not to lump it together with those due to the fact that even though it clearly refers to distinct groups, it does not identify specific rights to be protected. Hence, it includes such topics as national identity, traditional values, multiculturalism, and ethnonational.

Finally, the warfare category also deserves further deliberation. It embraces the topics, which do not fit either into the third-generational sphere of humanitarianism, or into mass atrocities, with unambiguous violation of the right to life. Instead, they broadly refer to conflicts of national or international concern. Thus, such topics as armed conflicts, civil wars, military intervention, and guerrilla warfare were placed into the warfare category.

The articles used in the analysis predominantly address the category of transition rights (176 articles in terms of absolute frequency). Within the category of transition rights, the class of rights which concerns the transitional justice is by far the most predominant category with 107 articles in absolute terms (see Table 5).

Considering the other types of rights from the group of uncategorized bigrams, warfare is the most discussed class of rights with 87 and 110 articles in terms of absolute and relative frequencies, respectively. This category is followed by the class of migration rights with 52 and 50 articles in terms of absolute and relative frequencies, respectively. Other classes of rights are not as present in the articles. Nevertheless, there is evidence of a somewhat more significant presence of the topics of identity, and security and terrorism (see Table 6).

Considering the most dominant class of rights, the most frequent bigrams belong to the category of transitional justice. By far the most frequently used bigram is "transitional justice" followed by "truth commission/s" and "truth (and) reconciliation."

Table 5 Distribution of articles across types of uncategorized rights (transition class)

\begin{tabular}{|c|c|c|c|c|}
\hline & Transition (total) & $\begin{array}{l}\text { Transition and } \\
\text { democratization }\end{array}$ & $\begin{array}{l}\text { History } \\
\text { and memory }\end{array}$ & $\begin{array}{l}\text { Transitional } \\
\text { justice }\end{array}$ \\
\hline Absolute frequency & 176 & 41 & 28 & 107 \\
\hline $\begin{array}{l}\text { Absolute frequency: bootstrapped } \\
95 \% \text { confidence intervals (rounded) }\end{array}$ & 158-194 & $29-53$ & $17-39$ & $91-123$ \\
\hline Relative frequency & 176 & 37 & 46 & 93 \\
\hline $\begin{array}{l}\text { Relative frequency: bootstrapped } \\
95 \% \text { confidence intervals (rounded) }\end{array}$ & $157-195$ & $26-48$ & $33-59$ & $77-109$ \\
\hline
\end{tabular}


Table 6 Distribution of articles across types of uncategorized rights

\begin{tabular}{|c|c|c|c|c|c|c|}
\hline & $\begin{array}{l}\text { Security } \\
\text { and terrorism }\end{array}$ & Sanctions & Migration & $\begin{array}{l}\text { Eugenics and } \\
\text { science }\end{array}$ & Warfare & Identity \\
\hline Absolute frequency & 26 & 10 & 52 & 1 & 87 & 26 \\
\hline $\begin{array}{l}\text { Absolute frequency: bootstrapped } \\
95 \% \text { confidence intervals } \\
\text { (rounded) }\end{array}$ & $16-36$ & $4-16$ & $39-65$ & $0-4$ & $77-102$ & $17-45$ \\
\hline Relative frequency & 31 & 12 & 50 & 1 & 110 & 37 \\
\hline $\begin{array}{l}\text { Relative frequency: bootstrapped } \\
95 \% \text { confidence intervals } \\
\text { (rounded) }\end{array}$ & $20-42$ & $5-19$ & $37-63$ & $0-4$ & $92-128$ & $26-48$ \\
\hline
\end{tabular}

Considering the class of history and memory from the transition category of rights, the most frequently used bigrams are "cultural relativism," "truth telling," "politics (of) memory," and "post(-)colonial." Finally, considering the class of transition and democratization, the most frequently used bigrams are as follows: "democratic transition," "transitional societies," and "political transition."

With respect to the other types of rights, as mentioned above, four categories stand out: warfare, migration, identity, and security and terrorism. The most frequently used terms with respect to warfare class of rights are "armed conflict/s," "civil war," "armed forces," "political violence," "military intervention," "civilian population/s," and "ethnic conflict." On the other hand, considering the migration class of rights, the most frequently used bigrams are "regulating immigration," "irregular immigrants," "migrant workers," and "migrants rights." With respect to the class of identity rights, the most frequently used bigrams are as follows: "traditional values," "national identity," "Islamic identity," and "Muslim communities." Finally, considering the class of security and terrorism, the most frequently used bigrams are "War (on) Terror," "anti-terrorist," and "terrorist violence."

\section{Discussion of the Results}

The results of the analysis present a few interesting points for reflection. Firstly, if to look at relative unigram (Table 2) and bigram (Table 3) frequencies, it is evident that words and word combinations "international," "global," "international human," and "United Nations," are more numerous and precede in frequency words such as "state," "national," and "domestic." It demonstrates that within the three journals, human rights tend to be discussed within the international context more frequently than in the context of nation states. Notwithstanding that the three journals' titles do not imply internationalization, it is obvious that the shift is towards the international, rather than domestic realm of human rights.

Secondly, the results displayed in Table 4 demonstrate that the most discussed generation of human rights is the first - civil and political liberties. Articles, which focus on this generation, amount to somewhat less than one-third of the total number. However, even though the most frequent bigram detected within this category is "civil 
society" - the central notion for this generation - the following bigrams are less straightforward. For example, the second most frequent bigram is "war crimes" and the fifth- "crimes (against) humanity." We include those word combinations into the first-generation category based on their focus on the protection of the right to life; however, this position can be debated since it does not unambiguously correspond to Vašák's definition. Thus, it shows that even though the first generation is the most numerous, the main focus lies not on the "classical" list of rights such as the rights to life, fair trial, assembly, and religion, but on the new concepts that generally follow the logic of the basic rights while functioning in a conflict environment and entail international response.

As for the second- and third-generation rights, on the contrary, the most frequent bigrams of those categories correspond to the list of rights mentioned by Vašák and international covenants quite neatly. For the second generation, those are "economic social" and "cultural rights," "rights (to) health," "right (to) education," (even though it should be noted that the European Convention on Human Rights puts right to education among the first-generation rights), etc. Similarly, the most frequent bigrams of the third generation are "self(-)determination," "developing countries," "peace process," and such alike. Hence, the discussion of those generations is more consistent with the theoretical framework.

The group rights category confirmed our observations with the most frequent topics of rights of women, indigenous people, children, LGBT rights, and racial discrimination. However, another noticeable group of topics is related to conflicts and postconflict environment (displaced persons, trafficking, and smuggling). These aspects diffuse the basic human rights principles to the unstable political environment at national, but even more to regional levels.

Finally, the most challenging part of the research concerns the uncategorized bigrams presented in Tables 5 and 6 . Within that category, by far, the most discussed topic is transition with transitional justice being its most popular aspect, followed by democratization and memory-related topics. The second largest group of articles among the uncategorized ones is devoted to warfare and its different aspects. Then, the following group is focused on migration, and approximately twice less popular are the topics of identity and terrorism, which also did not fit into Vašák's categorization.

Thus, the uncategorized group presents a fruitful area for discussion and amounts to the second largest category overall, preceded only by the first-generation rights. It demonstrates that the contemporary human rights discourse is overburdened with the topics that are too ambiguous for existing categorizations and require further reconsideration. Eventually, as it was rightfully predicted by Alston almost four decades ago, "the concept of third generation solidarity rights would seem to contribute more obfuscation than clarification in an area which can ill afford to be made less accessible to the masses than it already is" (Alston 1982, p. 322).

\section{Conclusion}

The main aim of the article was to investigate to what extent the contemporary human rights narrative corresponds to the applied categorizations of human rights over the last half a century. The research elaborated on Karel Vašák's comprehensive categorization 
of human rights and its theoretical foundations. Since that categorization was created almost half a century ago, we examined whether it is still encompasses the constantly expanding human rights discourse.

According to the results of our analysis, the topics that are too ambiguous to be categorized based on the Vašák's approach, constitute the second most numerous category, which indicates a substantial mismatch with Vašák's classification. Such a gray area primarily includes topics like transitional justice, reconciliation, truth commissions, terrorism, reparations, rights of migrants, forgiveness, reparations, and economic sanctions. As it becomes evident from the statistical data, these topics were widely discussed in the analyzed journals. However, when it comes to categorization, they do not fit into any of the categories due to their vagueness and ambiguity. Specifically, it is challenging to differentiate those topics based on the dichotomies of Vašák's categorization: negative vs. positive, individual vs. collective, and national vs. international rights. Hence, there may be several explanations for that: either those topics fall outside of the theoretical requirements of the human rights concept, or the framework of the concept itself is not developed enough to encompass all of the abovementioned topics.

Finally, the research also demonstrated that the first-generation rights - the classical freedoms and liberties - still receive significant attention. However, their context is internationalized and their content shifts towards the international context. Such "internationalization" of political and civil rights, usually associated with the relation between the state and the individual, might be a peculiarity of the three analyzed journals, but it constitutes an interesting trend that deserves further research. Another interesting fact emerges from the individual vs. collective dichotomy. Since both thirdgeneration and group rights refer to the collective, they compose a considerable counterbalance to the individual rights of the first generation.

Notwithstanding the limited scope of this research and with regard to the alternative approaches towards the concept of human rights, this survey reveals an interesting dilemma for the contemporary human rights narrative - the lack of comprehensive approach to categorization that is able to reflect the new developments of the theory. Undoubtedly, some of the topics that fell into the "no category" group in the present research could be narrowed down and further specified in order to fit the Vašák's division of human rights and be receptive to the criteria of that categorization. However, there is an apparent need for more exact criteria to what the human rights concept can and cannot incorporate without disturbing the balance of its framework. However, as noticed over the last forty years, from the introduction of the third generation through the recognition of the indivisibility of rights, the international human rights practice rather encourages the softening than tightening of requirements for what means to be a human right.

Vašák's categorization organized human rights in terms of importance, reference to freedom, or equality and ultimately as a guideline how to understand the particular rights. Our research has found that regardless of the continuing dominant position of the rights belonging to Vašák's first generation, the bulk of the debate (all other categorizations taken together) overshadow the primacy of civil and political rights. Our research findings suggest that there is a burning need for a new debate on the idea and importance of human rights: firstly, because within the human rights community the accent shifts from the primacy of freedom to the primacy of equality; secondly, 
because the post-Cold War liberal order settled around the human rights pillar faces unprecedented attack from illiberal regimes and the temptation for democratic backsliding; thirdly, because the power of human rights stemmed from its human (read individually)-centered approach. However, today, as our research reveals on this narrow sample, priority shifts noticeably towards collectives rather than individuals.

Open Access This article is distributed under the terms of the Creative Commons Attribution 4.0 International License (http://creativecommons.org/licenses/by/4.0/), which permits unrestricted use, distribution, and reproduction in any medium, provided you give appropriate credit to the original author(s) and the source, provide a link to the Creative Commons license, and indicate if changes were made.

\section{References}

Albuquerque A (2014) Interculturalism, Bioethics Perspectives, And Human Rights. Global Bioethics 2:8194.

Alston P (1982) A Third Generation of Solidarity Rights: Progressive Development or Obfuscation of International Human Rights Law? Netherlands International Law Review 3:307-322.

Baldissone R (2010) Human rights: a lingua franca for the multiverse. The International Journal of Human Rights 7:1117-1137.

Berlin I (1990) Four Essays on Liberty. Oxford University Press.

Bill of Rights (1791) United States Bill of Rights Ratified by the states on December 15, 1791. https://www. archives.gov/files/legislative/resources/education/bill-of-rights/images/handout-3.pdf. Accessed on 11 October 2018.

Bisztyga A (2011) Europejska Konwencja Praw Człowieka a Karta Praw Podstawowych Unii Europejskiej stan kompatybilności czy konkurencyjności? Przegląd Prawa Europejskiego 3:179-188.

Bojarski L, Schindlauer D, Wladasch K, Wróblewski M (2014) Karta Praw Podstawowych UE Jako Żywy Dokument, Podręcznik dla prawników. Warszawa, INPRIS.

Bunch C (1990) Women's Rights as Human Rights: Toward a Re-Vision of Human Rights. Human Rights Quarterly 12:486-498.

Carleton.ca (n.d.) Extension: About the Charter of Fundamental Rights. https://carleton. $\mathrm{ca} / \mathrm{ces} /$ eulearning/politics/human-rights/extension-about-the-charter-of-fundamental-rights. Accessed on July 152019.

Celik E (2017) The Role of CRPD In Rethinking The Subject Of Human Rights. The International Journal of Human Rights 7:933-955.

Council of Europe (1995) Framework Convention for the Protection of National Minorities.

Council of Europe (2018) The Right of Older Persons to Dignity and Autonomy in Care. https://www.coe. $\mathrm{int} / \mathrm{en} / \mathrm{web} / \mathrm{commissioner} /$-/the-right-of-older-persons-to-dignity-and-autonomy-in-care. Accessed on September 252018.

Declaration of the Rights of Man (1789). http://avalon.law.yale.edu/18th century/rightsof.asp. Accessed on 11 October 2018.

Dinham B, Malik S (2003) Pesticides and Human Rights. International Journal of Occupational and Environmental Health 1:40-52.

Donnelly J (1993) International Human Rights. Boulder, Westview Press.

Downs J (1993) A Healthy and Ecologically Balanced Environment: An Argument for a Third Generation Right. Duke Journal of Comparative \& International Law 2:351-386.

Fredman S (2006) Human Rights Transformed: Positive Duties and Positive Rights. Oxford Legal Studies Research Paper 38/2006, 498-520.

Fredvang M, Biggs S (2012) The Rights of Older Persons, Protection and Gaps Under Human Rights Law. Brotherhood of St Laurence and University of Melbourne Centre for Public Policy.

Freedman R (2014) Third generation' rights: is there room for hybrid constructs within International Human Rights Law? Cambridge Journal of International and Comparative Law, 2 (4). pp. 935959.

Grimme J, Brandon M S (2013) Text as Data: The Promise and Pitfalls of Automatic Content Analysis Methods for Political Texts. Political Analysis 1-31. 
Huntington S (1992) The Third Wave. Democratization in the Late Twentieth Century. University of Oklahoma Press.

Hurst Hannum (2019) Rescuing Human Rights. Cambridge University Press.

Ife J (2012) Human Rights and Social Work: Towards Rights Based Practice. Cambridge University Press.

Ishay M (2008) The History of Human Rights. Berkley, University of California Press.

Karadzhova M (2002) Universalni standarti za pravata na choveka. In Evgeni Tanchev, Osnovni prava na choveka, Iurispress, Universitetsko izdatelstvo, sv. Climent Ohridski, Sofia.

Kooijmans P H (1990) Human Rights - Universal Panacea? Some reflections on the so-called human rights of the third generation. Netherlands International Law Review, 37:315-329.

Kymlicka W (2018) Human Rights Without Human Supremacism. Canadian Journal of Philosophy 6:763792.

Łętowska E (2005) Multicentryczność Współczesnego Systemu Prawa i Jej Konsekwencje. Państwo i Prawo 3:3-10.

Magna Carta (1297) Available at: http://www.legislation.gov.uk/aep/Edw1cc1929/25/9/data.pdf. Accessed on 10 October 2018.

Mapulanga-Hulston J K (2002) Examining the Justiciability of Economic, Social and Cultural Rights. The International Journal of Human Rights 4:29-48.

Official Journal of the European Communities (2000) Charter of Fundamental Rights of the European Union, 2000/C 364/01. http:/www.europarl.europa.eu/charter/pdf/text_en.pdf. Accessed on 25 November 2018.

Organization of African Unity (OAU) (1982) African Charter on Human and Peoples' Rights ("Banjul Charter").

Pelluchon C (2008) Toward a New Philosophical Anthropology: The Limits of Human Rights in Bioethics. Perspectives on Political Science 1:31-40.

Raposo V L (2016) The Convention Of Human Rights And Biomedicine Revisited: Critical Assessment. The International Journal of Human Rights 8:1277-1294.

Robertson J (2014) Human Rights vs. Robot Rights: Forecasts from Japan. Critical Asian Studies 4:571-598.

Ssenyonjo M (2011) Reflections on state obligations with respect to economic, social and cultural rights in international human rights law. The International Journal of Human Rights 6:969-1012.

Stein M A (2007) Disability Human Rights. California Law Review 95:75-121.

Teitel R (2003) Transitional Justice Genealogy. Harvard Human Rights Journal 16:69-97.

Tomuschat C (2014) Human Rights: Between Idealism and Realism. Oxford University Press.

UN General Assembly (1948) Universal Declaration of Human Rights, 217 A (III). https://www.ohchr. org/en/udhr/documents/udhr_translations/eng.pdf. Accessed on 12 September 2018.

UN General Assembly (1966a) International Covenant on Civil and Political Rights. https://www.ohchr. org/Documents/ProfessionalInterest/ccpr.pdf. Accessed on 15 September 2018.

UN General Assembly (1966b) International Covenant on Economic, Social, and Cultural Rights. https://www.ohchr.org/Documents/ProfessionalInterest/cescr.pdf. Accessed on 15 September 2018.

UN General Assembly (1972) Declaration of the United Nations Conference on the Human Environment (Stockholm Declaration). https://mwvlw.rlp.de/fileadmin/mwkel/Abteilung_2/8206/06_Nachhaltigkeit_ global/1972_Stockholm_Erklaerung_en.pdf. Accessed on 21 October 2018.

UN General Assembly (1986) Declaration on the Right to Development. https://www.un. org/documents/ga/res/41/a41r128.htm. Accessed on 1 November 2018.

UN General Assembly (1992) Rio Declaration on Environment and Development. http://www.unesco. org/education/pdf/RIO_E.PDF. Accessed on 21 October 2018.

UN General Assembly (2007) United Nations Declaration on the Rights of Indigenous Peoples. https:/www. un.org/esa/socdev/unpfii/documents/DRIPS_en.pdf. Accessed on 1 November 2018.

Uvin P. (2002) From the Right to Development to the Rights-Based Approach: How 'Human Rights' Entered Development. Development in Practice 17:598-599.

Vašák K (1977) Human Rights: A Thirty-Year Struggle: the Sustained Efforts to give Force of law to the Universal Declaration of Human Rights. UNESCO Courier, 11:29-32.

Vienna Declaration and Programme of Action (1993) Vienna Declaration and Programme of Action Adopted by the World Conference on Human Rights in Vienna on 25 June 1993. https://www.ohchr. org/EN/ProfessionalInterest/Pages/Vienna.aspx. Accessed on 10 July 2019.

Wang Z (2013) Toward a Postmodern Notion of Human Rights. Educ Philos Theory 34(2):171-183

Wellman C (2000) Solidarity, the Individual, and Human Rights. Human Rights Quarterly 22:639-657.

Publisher's Note Springer Nature remains neutral with regard to jurisdictional claims in published maps and institutional affiliations. 